\title{
The Relationship between Audit Committee Characteristics, Audit Firm Quality and Companies' Profitability
}

\author{
Laith A. Aryan \\ Dept. of Accounting, Ajloun National University \\ P.O.Box 43, Ajloun 26810, Jordan \\ Tel: 962-2-646-6616 E-mail: Laith.aryan@anu.edu.jo
}

Received: August, 5, 2015 Accepted: Nov. 9, 2015 Published: December 9, 2015

doi:10.5296/ajfa.v7i2.8530 URL: http://dx.doi.org/10.5296/ajfa.v7i2.8530

\begin{abstract}
Jordan displayed keen interest in corporate governance in terms of enhancing the quality of financial statements and to restore the investors' confidence. This study aimed to highlight the role of audit committee and external audit in enhancing companies' profitability. Since there are contradictions in previous studies results, there is a need to test these relationships in Jordanian context to provide empirical evidence on this issue, especially after the corporate governance application became mandatory since 2009. This study has used industrial sector, which include 91 companies, only 69 companies were included in this study, the other 22 companies were excluded either newly listed or delisted during the study period (2009-2014). Multiple regression were used to analyze the data, the result showed positive relationships between audit committee meeting, audit committee size and companies profitability, while no significant relationship between audit committee composition, audit committee members literacy, audit quality and companies profitability. Such results would be beneficial to companies' corporate governance committees to play their supervisory role.
\end{abstract}

Keywords: Audit committee, Audit quality, Profitability, Jordan 


\section{Introduction}

The world has witnessed a big financial turmoil during the last few years, which led many big firms to go bankrupt. Therewith, the investors became distrustful in the reliability of the global financial markets and the companies' financial information as well. As a result, interest in corporate governance has increased in both developed and developing countries in an attempt to regain the lost confidence.

Jordan also displayed keen interest in corporate governance in terms of enhancing the quality of financial statements. In doing so, the legislators have enacted laws to ensure public companies to apply corporate governance roles. In September 2009 JSC issued the Corporate Governance Code for Shareholding Companies Listed on the Amman Stock Exchange which defines the responsibilities and formation of the committees.

Corporate governance code describes the committees formed by the board of directors such as audit committee. JSC (2009) stipulates that the members of audit committee must have knowledge in finance or accounting, and at least one of them must have worked previously in accounting or finance fields; and that person must have an academic or professional certificate in accounting, finance or related fields. Also, this code ensures audit committee periodically meet and at least one meeting with external auditor must be held. The duties of audit committee are determined as follows: (1) discussing matters related to the nomination and working of the external auditor and reviewing the company's correspondence with the external auditor; (2) monitoring the company's compliance with laws and regulations in force and the requirements of regulatory institutions; (3) monitoring any change in the company's accounting policies, and any change in the company's accounts as a result of the auditing processes; (4) evaluating the internal control and auditing procedures and the auditor evaluation for internal control; and (5) ensuring that no conflict of interest may arise from the company's transactions, contracts or projects with related parties. The code also points out the power of audit committee, which are: (1) requesting the presence of the external auditor if the committee sees a need to meet him regarding his work; (2) nominating the external auditor to the board of directors for election by the general assembly; and (3) nominating a candidate to be appointed as the company's internal auditor (JSC, 2009)

OECD (2005) defines corporate governance as "procedures and processes according to which an organization is directed and controlled. The corporate governance structure specifies the distribution of rights and responsibilities among the different participants in the organization such as the board, managers, shareholders and other stakeholders and lays down the rules and procedures for decision-making".

Audit committee and external audit play an important role in enhancing the quality of financial statements and the firm financial performance by mitigating financial distress, such results is supported by many researchers. For example, Salloum, Azzi, Gebrayel (2014)found that the financial distress of banks has a significant negative relation with the meeting frequency of the audit committee. Geiger and Rama (2006) asserted that the big audit firms provide a high quality report in terms of producing lower errors compared with the non-big audit firms. 
In light of previous studies' results, this study came to highlight the role that the audit committee characteristics and external audit can play to control the management actions and controlling the agency problems. The need for such study is to bridge the gap in literature since these relationships has not been researched extensivelyin Jordan. Moreover Jordan has witnessed many financial scandals that led many companies to go bankrupt such as Global Business, and Alshamyleh Gate. Thus Jordan has issued the code of conduct in 2009 which require listed companies to form the committees as explained earlier.

\section{Literature Review}

Many researchers have examined the relationship between audit committee, audit quality and companies' profitability, for example, Merawati (2015) conducted his study on 11 insurance and reinsurance companies listed in the Indonesian Stock Exchange in 2012, the results showed that the Audit Committee, the Internal Audit, the External Audit and the corporate financial soundness, have influences on the company's profitability. Vuko, Maretić, and Čular (2015) analyzed the role and effectiveness of internal mechanism (audit committee) of corporate governance on credit institutions performance in Croatia. sample consisted of 78 credit institutions listed in Zagreb Stock Exchange, from 2007 to 2012 has been collected and efficiency index of audit committee (EIAC) has been created. They found that audit committees of credit institutions have medium efficiency, and there is a significant difference in audit committee effectiveness in observed period, moreover there is a significant difference between level of audit committee effectiveness and audit firm type. While there is no positive relationship between audit committee effectiveness and credit institution performance.

Narwal and Jindal (2015) examined the impact of corporate governance on the profitability of Indian textile sectors. They collected data from annual reports of textiles companies for the period of five year ranging of 2009to 2014. The profitability has been taken as dependent variable and board size, audit committee members, board meetings, non-executive directors, directors remunerations as independent variables. For analyzing the data they used correlation and OLS regression model in this study. Finally, they found a strong positive association is observed between director's remuneration and profitability. The Audit Committee members is observed negative associated with the profitability. The study concluded that board size, board meeting and non-executive directors do not significant association with the profitability

On Contrary, Ojulari (2014) explores the relationships that exist between corporate governance and the performance of Quoted Companies in Nigeria. He selected twenty five companies listed in the Nigerian stock exchange. The results show that the two variables (i.e. corporate governance and financial performance) are more positively related on an individual proxy basis than on an overall proxy basis. The overall impact of corporate governance on the performance is also negative so also are the result of the regression models. This result shows that although there is a relationship between the two variables, the predictive power of corporate governance on companies' performance is too low to be meaningful. Salloum, et al(2014) aimed to highlight the impact of audit committee characteristics on Lebanese financially distressed and non-distressed banks. They examined four characteristics of the 
audit committee (i.e. size, composition, frequency of meeting and financial expertise. They found that the distressed banks have a significant negative relation with the meeting frequency of the audit committee. They added that meeting frequency plays an important role to ensure audit committee effectiveness and the audit committee with frequent meetings is able to help audit committee members to ensure the integrity of financial reporting, to provide better monitoring and to review effectively the operations. Fulop (2013) analyzed the correlations between the audit committee and profitability. He used 25 companies listed on Berlin Stock Exchange to test these relationships he found that the role of the audit committee is crucial. Similarly Zare et al (2013) examined the relationship between audit firm size and profitability. They used 97 companies' annual reports to test the study hypotheses; they found a negative and significant relation between audit firm size institution and companies profitability. Moreover, Arshad et al (2011) found a there is positive effect of an audit committee on firm's profitability ratio and on firm's performance.

Zahirul-Islam (2010) argues that an audit committee is one way to reduce the management incentive problem - such as manipulating financial statements to get higher bonuses. This is because effective audit committees enhance the quality and credibility of annual audited financial statements. Goodwin and Seow (2002) found that the presence of a strong audit committee decreases errors in financial statements and increases the possibility of management fraud detection. Song and Windram (2004) found weak evidence on the relationship between the member financial literacy, meeting frequency, and outside directorships, and the effectiveness of audit committee. Al-Shareif (2008) found a positive relationship between independent audit committee and earnings quality in Jordan. Ismail et al. (2008) revealed that only audit committee with multiple directorship members is related positively to the quality of reporting. Meca and Ballesta (2009) found that independent audit committee is an effective mechanism in mitigating earnings management. Wan-Hussin and Haji-Abdullah (2009) examined the relationship between audit committee and the quality of financial statements in Malaysia. They found that the presence of a big audit committee is related positively with quality of financial reporting. Similarly, Rainsbury et al. (2009) studied the relationship between the quality of audit committee and the financial reporting quality. They found no significant relationship between the quality of an audit committee and the quality of financial reporting. They remarked that this surprising result suggests that the benefits of high quality audit committee may be less expected by regulators and decision makers. Al-khabash and Al-Thuneibat (2008) demonstrated that poor corporate governance such as the absence of an audit committee correlates positively and significantly with illegitimate earnings management. Also, Ismail et al. (2009) found that the size of the audit committee is positively correlated with earnings quality. Lin and Hwang (2010) found that earnings management has a negative relationship with independence, expertise, and number of meetings of audit committee. Contrarily, Wenyao and Qin (2008) concluded that presence of audit committee did not reduce income-increasing earnings management. In Jordan, Al-khabash and Al-Thuneibat (2008) found that the absence of audit committee correlated positively with earning management, which confirms agency theory's assertion that is the presence of an audit committee enhances the quality of financial statements. 
Watts and Zimmerman (1990) state that an auditor plays a significant role in monitoring managements' behavior, which reduces the agency costs, similarly, Xiao et al. (2004) note that agency theory postulates that audit mitigates the interest conflict between contracted parties. They add that big audit firms are more likely to be hired by managements with greater potential gains from external monitoring. Salehi and Mansoury (2009) assert that because large audit firms have their own resources such as superior technology and talented employees, these enable them to issue reports of higher quality than small audit firms do.

Agency theory proposes that because a big audit firm has a reputation that needs to be maintained they will perform better in their job(Naser, 1998).Dietrich, Harries and Muller (2001) indicated that the reliability of fair value estimations is higher when the firm is monitored by external auditors especially the big audit firms. Bauwhede, Willekens, and Gaeremynck (2003) found that hiring one of the Big auditors decreases the earnings management. Geiger and Rama (2006) found that the big audit firms provide a high quality report in terms of producing lower errors compared with the non-big audit firms. Hayyani (2008) argue that big audit firms are better in predicting failure in companies in Jordan. Teitel and Machuga (2010) provided evidence on the relationship between the audit quality and earnings quality. They found companies that hire a high quality auditor show a high earnings quality. Similarly, Bauwhede and Willekens (2003) found a negative relationship between audit firm size and earnings management. In the contrary,Moroney and Dowling (2005) found no relationship between audit firm size and the auditor performance level. Shanikat and Abbadi (2011) indicated that the audit profession in Jordan is dominated by big audit firms and a few smaller national audit firms. Hence, they concluded that, in general, audit firms in Jordan are of low quality.

In Malaysia, Ismail, et al (2008) investigated the relationship between audit committee and external audit with quality of financial reporting for 45 companies listed on the Bursa Malaysia. They found that only the audit committee with multiple directorship members is positively related to the quality of reporting. They also found no relationship between the audit quality and quality of corporate reporting. Shanikat and Abbadi (2011) argued that the audit profession in Jordan is dominated by big audit firms and a few smaller national audit firms. They also noted that most audit firms in Jordan are of low quality.

Al-Shareif (2008) examined the relationship between corporate governance and earnings quality in Jordan. He revealed that the independent audit committee correlates positively with earnings quality, while there is no relationship between board size and board independence with earnings quality. Correspondingly, Al-Khabash and Al- Thuneibat (2008) explored earnings management practices in Jordan from the perspective of external and internal auditors. They found that the external and internal auditors believe that the management involves significantly in legitimate earnings management by decreasing or increasing the income, but the internal auditors believe that the management increases the income only. They also found no significant differences between small and big firms concerning earnings management practices. They demonstrated that poor corporate governance such absence of an audit committee, combination of the $\mathrm{CEO}$ and founder roles, and board of directors dominated by insiders correlate positively and significantly with illegitimate earnings 
management. Segovia (2003) tested the role of auditors in approving earnings management. He stated the current standards facilitate earnings management in companies. He added that interpretation of GAAP confuse the auditors' decision making.

\section{Methodology}

This study extracted data from industrial companies' annual reports for six years (2009-2014) to test the relationship between audit committee characteristics (i.e. audit committee size, audit committee composition, meeting frequency, and financial literacy), audit quality and companies' profitability. Hair et al (2007) assert that some of the advantages of using secondary data are that it saves time and cost of acquiring the information generated. It is helpful to acquire the actual state of phenomenon under study.

Data were collected from the industrial sector only because this sector makes up $48 \%$ of Amman Stock Exchange (ASE), the financial sector was excluded because it has different regulations and corporate governance code. To choose the companies relevant to the study, they had to meet two conditions:

1. The company has financial statements data for the study period. Companies that are newly listed or delisted during the study period were excluded.

2. The companies traded regularly in the ASE during the study period.

\subsection{MEASUREMENT}

This study has used many proxies to measure the dependent and independent variables. The audit committee characteristics as mentioned in Jordanian code of conduct are audit committee size, audit committee composition, meeting frequency, and financial literacy. This study used the audit firm size as a proxy to measure audit quality. These measurements are explained below:

\begin{tabular}{ll}
\hline MEASUREMENT & \\
\hline Audit committee size & The number of audit committee members \\
Audit committee composition & The ratio of non-executives members \\
Meeting frequency & The number of meeting held per year \\
Financial literacy & The number of members who have a financial \\
& Knowledge \\
Audit quality & $1=$ Big 4 audit firm \\
& $0=$ Non big 4 audit firm \\
Profitability & Gross Profit Margin: The gross profit margin \\
& is calculated as follows: \\
& (Sales - Cost of Goods Sold) / Sales \\
\hline
\end{tabular}

\subsection{Population and Sample Selection}

Sekaranand Bougie(2013) refer to population as the entire group, events, or things of interest that the researcher wishes to investigate, and the sample is a subset of the population. In this study, the population is industrial sector which consisted from 91 companies. Out of 91 
companies, 22 companies were excluded because they did not meet the abovementioned conditions.

\section{Hypotheses of the Study}

Based on the aforementioned argument and previous studies results, and following agency theory assumptions, the hypotheses of this study are formulated as following:

H1: There is a significant relationship between audit committee size and company's profitability.

$\mathrm{H} 2$ There is a significant relationship between the composition of non-executive directors in audit committee and company's profitability.

H3: There is a significant relationship between the frequency of audit committee's meeting and company's profitability.

H4: There is a significant relationship between the financial literacy of audit committee's members and company's profitability.

H5: There is a significant relationship between audit quality and company's profitability

The model used to test the above hypotheses is as follows:

PROFIT $=\alpha+\beta 1$ ACSIZE $+\beta 2$ ACCOMP $+\beta 3$ ACMEET $+\beta 4$ ACLITR $+\beta 5$ AUFSIZE $+\varepsilon$

Where:

PROFIT

Profitability

ACCOMP

Size of audit committee

ACMEET

The frequency of audit committee meeting

ACLITR

Financial literacy of audit committee members

AUFSIZE

Audit firm size

$\alpha=$

Constant; and

$\varepsilon=$

Disturbance term.

\section{Hypotheses Testing}

Before testing the hypotheses testing, this study has checked linearity, normality, and homoscedasticity. The need for normally distributed data is because the correlation represents a linear association between the variables while the nonlinear association is not represented. So the scatter plots should express the normal line for the independent and dependent variables. According to Hair et al. (2010), testing the normality of the data can be done by exploring skewness and kurtosis ratio. Normality is assumed when the skewness and the kurtosis are between \pm 1.96 at alpha value .05 and \pm 2.58 at alpha .01 , respectively. The values of skewness and kurtosis indicate that the data were normally distributed.

The results of multiple regression showed that $\mathrm{R}^{2}$ is 0.319 that means the independent variables explain $31.9 \%$ of dependent variable as shown in table 1 below. 
Table 1.

\section{Model Summary}

\begin{tabular}{llccc}
\hline Model & R & R Square & Adjusted R Square & Std. Error of the Estimate \\
\hline 1 & $.345^{\mathrm{a}}$ & .319 & .299 & .038 \\
\hline
\end{tabular}

The results of hypotheses testing shows there is a positive relationship between audit committee size, audit committee meetings and profitability. While there is no relationship between audit committee composition, audit committee members literacy, audit quality and company's profitability. Table 2 summarizes these results.

Table 2.

\section{Coefficients}

\begin{tabular}{lllllll}
\hline Model & \multicolumn{5}{c}{ Standardized } \\
& & & \multicolumn{2}{c}{ Unstandardized Coefficients } & Coefficients \\
& & B & Std. Error & Beta & $\mathrm{t}$ & Sig. \\
\hline 1 & (Constant) & .320 & .024 & & 1.350 & .018 \\
& ACSIZE & .384 & .080 & .359 & 2.007 & .049 \\
& ACCOMP & .162 & .134 & .344 & 2.710 & .102 \\
& ACMEET & .198 & .158 & .181 & 1.782 & .038 \\
& ACLITR & .004 & .023 & .026 & .183 & .289 \\
& AUFSIZE & .033 & .124 & .034 & .262 & .194 \\
\hline
\end{tabular}

Dependent Variable: Profitability

Where:

$\begin{array}{ll}\text { ACSIZE } & \text { Audit Committee Size } \\ \text { ACCOMP } & \text { Audit Committee composition } \\ \text { ACMEET } & \text { Audit Committee Meetings } \\ \text { ACLITR } & \text { Audit Committee members Literacy } \\ \text { AUFSIZE } & \text { Audit Firm Size }\end{array}$

\section{Conclusions}

This study aimed to test the relationship between audit committee's characteristics, external audit quality and profitability empirically. In doing so, I extracted data from companies' annual reports to measure the study variables.

The results of the study supported some previous studies (i.e. Merawati (2015) Vuko, Maretić, and Čular (2015) Narwal and Jindal (2015)) partially, for instance, Merawati (2015) concluded that the Audit Committee, the External Audit and the corporate financial soundness, have influences on the company's profitability. Salloum, et al (2014) found that the distressed banks have a significant negative relation with the meeting frequency of the audit committee. 
Regarding to the relationship between audit quality, Zare et al (2013) found a negative and significant relation between audit firm size and companies profitability. While this study found no relationship, this may refer to the low quality of audit firms as Shanikat and Abbadi (2011) claimed that the audit profession in Jordan is dominated by big audit firms and a few smaller national audit firms. Hence, they concluded that, in general, audit firms in Jordan are of low quality.

Due to the contradicting pervious studies' results on this issue, this study came to expand the literature on the relationship between audit committee characteristics, external audit and profitability and to provide empirical evidence on these relationships in Jordanian context. Such empirical study will be helpful in shedding light on the supervisory role of audit committee and external audit companies' financial performance.

Such results highlighted the role of audit committee in enhancing companies' profitability, by exercising its supervisory role. Thus companies have to concentrate on audit committee size and increase the number of meetings as they have positive relationships to profitability.

\section{References}

Al-Khabash, A., \& Al-Thuneibat, A. (2008). Earnings management practices from the perspective of external and internal auditors: Evidence from Jordan. Managerial Auditing Journal, 24(1), 58 - 80.http://dx.doi.org/10.1108/02686900910919901

Al-Shareif, E. (2008). The relationship between corporate governance and earnings quality.Journal of Business Administration, $\quad 13(2), \quad 38-52$. http://dx.doi.org/10.1016/j.adiac.2008.08.011

Arshad, M. A., Satar, R. A., Hussain, M., \& Naseem, M. A. (2011). Effect of Audit on Profitability: A Study of Cement Listed Firms, Pakistan. Global Journal of Management and Business Research, 11(9), 8-12.

Bauwhede, H. V., \& Willekens, M. (2003). Earnings management in Belgium: A review of the empirical evidence. Tijdschriftvoor Economieen Management, 48(2), 199-217.

Bauwhede, H. V., Willekens, M., \& Gaeremynck, A. (2003).Audit firm size, public ownership, and firms' discretionary accruals management. The International Journal of Accounting, 38, 1-22.

Dietrich, J. R., Harris, M. S., \& Muller, K. A. (2001). The reliability of investment property fair value estimates. Journal of Accounting \& Economics, 30(1), 125-158. http://dx.doi.org/10.1016/S0165-4101(01)00002-7

Fülöp, m. T. (2013).Correlation analysis of the audit committee and profitability indicators. Annals of the University of Petroşani, Economics, 13(1), 139-148.

Geiger, M. A., \& Rama, D. V. (2006). Audit firm size and going-concern reporting accuracy. Accounting Horizons, 20(1), 1-17. http://dx.doi.org/10.2308/acch.2006.20.1.1 
Goodwin, J., \& Seow, J. L. (2002). The influence of corporate governance mechanisms on the quality of financial reporting and auditing: Perceptions of auditors and directors in Singapore. Accounting \& Finance, 42(3), 195-223. http://dx.doi.org/10.1111/1467-629X.t01-1-00074

Hair, J. F., Black, W. C., Babin, B. J., Anderson, R. E., \& Latham, R. (2010). Multivariate data analysis $\left(7^{\text {th }} \mathrm{ed}\right)$. New Jersey: Pearson.

Hayyani, A. (2008). The prediction of business failure in Jordan.Journal of Business Administration, 23(2), 123-146.

Ismail, H., Iskandar, T.M., \& Rahmat, M. M. (2008).Corporate reporting quality, audit committee and quality of audit.Malaysian Accounting Review, 7(1), 21-43.

JSC, Jordanian Securities Commission. (2009). Corporate governance code for shareholding companies listed on Amman Stock Exchange. 1-16. Retrieved from: http://www.sdc.com.jo/arabic/images/stories/pdf/corporate_governance_companies.pdf

Lin, J. W., \& Hwang, M. I. (2010). Audit quality, corporate governance, and earnings management: A meta-Analysis. International Journal of Auditing, 14(1), 57-77. http://dx.doi.org/10.1111/j.1099-1123.2009.00403.x

Meca, E. G., \& Ballesta, J. P. S. (2009). Corporate governance and earnings management: A meta-analysis. Corporate Governance: An International Review, 17(5), 594-610. http://dx.doi.org/10.1111/j.1467-8683.2009.00753.x

Merawati, E. E. (2015). The effect of the supervision by the Audit Committee, Internal Audit, External Audit and Corporate Financial Soundness on Profitability.International Journal of Business and Management Invention, 4(5), 65-71.

Moroney, R., \& Dowling, C. (2005). Auditor performance variation: Impact of audit firm size and industry regulation. Working Paper, Monash University. Retrieved from: http://www.abis.ecom.unimelb.edu.au/pdfs/research/WorkingPapers05/0503\%20Moroney\%2 0and\%20Dowling.pdf

Narwal, K. P., \& Jindal, S. (2015). The Impact of Corporate Governance on the Profitability: An Empirical Study of Indian Textile Industry International Journal of Research in Management, Science \& Technology 3(2).

Naser, K. (1998). Comprehensiveness of disclosure of non-financial companies Listed on the Amman financial market. International Journal of Commerce \& Management, 8(1), 88-119.http://dx.doi.org/10.1108/eb047365

OECD. (2004). Corporate governance definition. Retrieved from: http://stats.oecd.org/glossary/detail.asp?ID $=6778$

Ojulari, O. M. (2014). The Impact of Corporate Governance on Performance of Quoted companies in Nigeria. Paper presented at the the First Middle East Conference on Global Business, Economics, Finance and Banking, Dubai. 
Rainsbury, E. A., Bradbury, M., \& Cahan, S. F. (2009). The impact of audit committee quality on financial reporting quality and audit fees. Journal of Contemporary Accounting \& Economics, 5, 20-33. http://dx.doi.org/10.1016/j.jcae.2009.03.002

Salloum, C., Azzi, G., \& Gebrayel, E. (2014). Audit Committee and Financial Distress in the Middle East Context: Evidence of the Lebanese Financial Institutions. International Strategic Management Review, 2, 39-45. http://dx.doi.org/10.1016/j.ism.2014.09.001

Salehi, M., \& Mansoury, A. (2009). Firm size, audit regulation and fraud detection: Empirical evidence from Iran. Journal of Management, 4(1), 5-19.

Segovia, J. R. (2003). Earnings management: Do the type of GAAP, persuasive client explanation, and SEC notification influence the auditors' decisions. Texas Tech University, Texas. http://hdl.handle.net/2346/12651

Sekaran, U., \& Bougie, R. (2013). Research methodology for business: A skill building approach (6th ed.). Australia: Wiley \& Sons.

Shanikat, M., \& Abbadi, S. S. (2011). Assessment of corporate governance in Jordan: an empirical study. Australian Accounting Business and Finance Journal, 5(3), 91-106.

Song, J., \& Windram, B. (2004). Benchmarking audit committee effectiveness in financial reporting. International Journal of Auditing, 8(3), 195-205.

Teitel, K., \& Machuga, S. (2010). The interaction of audit firm quality and the Mexican code of best corporate practices on earnings quality. Review of Business Research, 10(1), 1-22. http://dx.doi.org/10.1111/j.1099-1123.2004.00090.x

Wan-Hussin, W. N., \& Haji-Abdullah, N. M. (2009).Audit committee attributes, financial distress and the quality of financial reporting in Malaysia, 1-40. Retrieved from http://ssrn.com/abstract $=1500134$

Watts, L., \& Zimmerman L. (1990). Positive accounting theory: A ten year perspective. The Accounting Review, 65(1) 131-156.

Wenyao, L., \& Qin, L. (October, 2008). Board composition and earnings management. Paper presented at the 4th international conference on wireless communications, networking and mobile computing, Dalian, China.

Vuko, T., Maretić, M., \&Čular, M. (2015). The Role and Effectiveness of Audit Committee inCorporate of Credit Institutions. International Journal of Social, Behavioral, Educational, Economic, Business and Industrial Engineering 9(4). Governance

Xiao, J. Z., Yang, H., \& Chow, C. W. (2004). The determinants and characteristics of voluntary Internet-based disclosures by listed Chinese companies. Journal of Accounting and Public Policy 23(3), 191-225. http://dx.doi.org/10.1016/j.jaccpubpol.2004.04.002

Zahirul-Islam, M. (2010). Agency problem and the role of audit committee: implications for corporate sector in Bangladesh. International Journal of Economics and Finance, 2(3), 177-188. http://dx.doi.org/10.5539/ijef.v2n3p177 


\section{Macrothink}

Asian Journal of Finance \& Accounting ISSN 1946-052X 2015, Vol. 7, No. 2

Zare, R., Khedri, S., \& Farzanfar, F. (2013). Examining the Effect of Auditing Institution, Internal Auditing Department and Companies' Profitability on Voluntary Information Disclosure in Tehran Stock Exchange. International Journal of Economy, Management and Social Sciences, 2(9). 